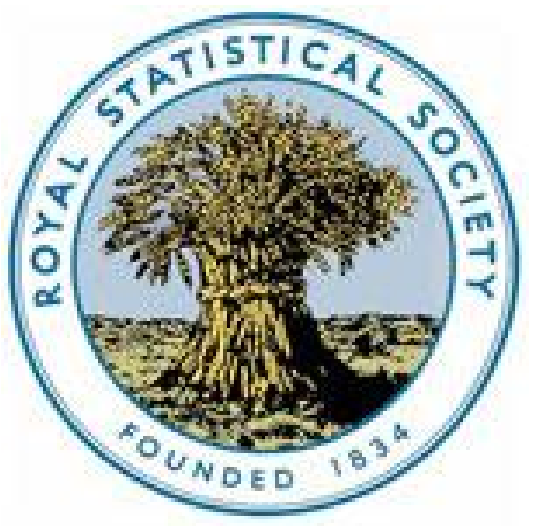

\title{
WILEY
}

\section{The Feasibility of Compulsory Education in Ireland}

Author(s): W. Neilson Hancock

Source: Journal of the Statistical Society of London, Vol. 42, No. 2 (Jun., 1879), pp. 456479

Published by: Wiley for the Royal Statistical Society

Stable URL: http://www.jstor.org/stable/2339145

Accessed: 27-06-2016 05:05 UTC

Your use of the JSTOR archive indicates your acceptance of the Terms \& Conditions of Use, available at

http://about.jstor.org/terms

JSTOR is a not-for-profit service that helps scholars, researchers, and students discover, use, and build upon a wide range of content in a trusted digital archive. We use information technology and tools to increase productivity and facilitate new forms of scholarship. For more information about JSTOR, please contact support@jstor.org.

Royal Statistical Society, Wiley are collaborating with JSTOR to digitize, preserve and extend access to Journal of the Statistical Society of London 


\section{The Feasibility of Compdisory Eddcation in Ireland.}

$B y$ W. NeILson Hancock, Esq., LL.D., M.R.I.A.

[Read before'the Statistical Society, 6th May, 1879.]

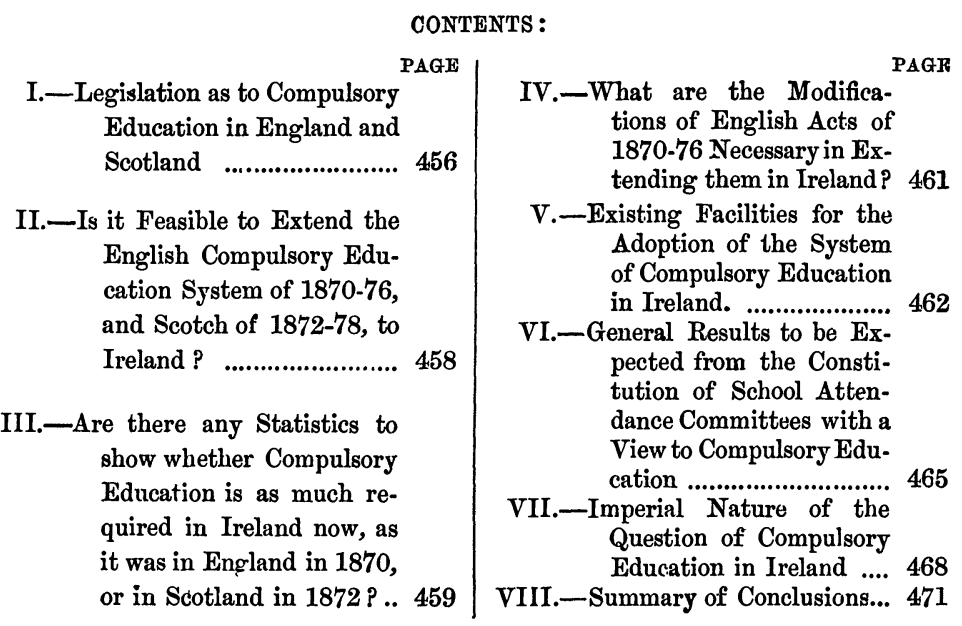

INVITED to read a paper before this Society, I have selected a subject, the solution of which rests largely on the results of statistical research.

It is a branch of the Irish education question, which is one of the most urgent and important of Irish subjects that awaits a solution in the near future.

As the question is one of considerable difficulty, I would not have ventured to discuss it, were it not that from having been Secretary of two commissions of Irish education inquiry, the Dublin University Commission of.1851-53, and the Endowed Schools Ireland Commission of 1854-58, the Irish education question has been very much before my mind for the past quarter of a century.

\section{I.-Legislation as to Compulsory Education in England and Scotland.}

Without referring to the common legislation for England, Scotland and Ireland, for securing the education of children employed in factories, I will commence with noticing the system of general compulsory education introduced in England in 1870, and in Scotland in $\mathbf{1 8 7 2 .}$ 
In 1870, by Mr. Forster's Elementary Education Act, English school boards were enabled to make bye laws requiring parents of children between 5 and 13 years of age, to cause them to attend school.

In 1872, by the Scotch Education Act of that year, parliament made it obligatory on every parent in Scotland to provide elementary education for their children between 5 and 13 .

It further imposed upon the local poor law authority the obligation of paying out of local rates the school fees, or portion of school fees, where parents were unable to pay them.

The Scotch Act further protected children under 13 years of age, by making every employer of such children as domestic servants, farm servants, or workers in mines, factories, or workshops, liable to the duty of a parent in respect of the child's instruction, unless the child had received three years' regular instruction after 5 , and was able to read and write.

In 1873 an Act was passed to regulate the employment of children in agriculture in England. It secured one of the objects of the Scotch Act, but in a slightly different manner; it prohibited the employment in agriculture of children under 8 years of age, except on land in the occupation of the parent, guardian or person who is liable to maintain the child; above 8 years of age protection was secured by requiring 250 school attendances before employment if under 10 years of age, and 150 in the preceding year if of 10 years of age or upwards.

In 1876 the English legislation in the matter of compulsory education was carried the whole length of the Scotch legislation, and it was enacted by Lord Sandon's Elementary Education Act that:-

"It shall be the duty of the parent of every child, to cause " such child to receive efficient elementary instruction in reading, " writing, and arithmetic, and if the parent fail to perform such "duty, he shall be liable to such orders and penalties as are "provided by the Act."

The Agricultural Children's Act of 1873 was repealed by Lord Sandon's Act, but more carefully framed provisions are substituted for it for protecting the employment of all children.

The enforcement of this statute is in the parts of England and Wales where there are school boards (with 13,000,000 population), entrusted to school boards, but for school districts not within the jurisdiction of school boards (with 9,700,000 population), there are provisions for the Act being enforced by a school attendance committee, which is to be appointed annually; if it is within a separate borough, by the council of the borough, and if it is a parish, by the guardians of the union comprising the parish. Urban sanitary 
authorities may, if allowed by special order, have the appointment in their district.

The observance of the provisions of the Act by employers of children in factories, workshops and mines, is entrusted to factory inspectors, the school attendance committee, however, to assist them in the performance of their duty.

The Act of 1876 changes some provisions of what was called Denison's Act, as to education of children of parents receiving outdoor relief, into a general principle identical to that I have referred to as having been passed for Scotland in 1872, by which, in case of poor parents, the payment is provided for out of the poor rates of school fees not exceeding $3 d$. a-week, or so much as the parent is unable to pay, without such assistance having disqualifying effect of pauper relief.

The Act contains some development of the industrial school system, and some provisions for day industrial schools on the original plan of this form of charity as advocated by Sheriff Watson in Scotland, and by the late Miss Carpenter in England.

The Scotch Act of 1878 extends to Scotland the English provisions (with slight modification) for regulating the employment of children, and securing education before employment of those over 10 .

From this great social code, developed by parliament in the past nine years, and applying to every child in England, and Scotland, every child in Ireland is entirely excluded.

\section{II.-Is it Feasible to Extend the English Compulsory Education System of 1870-76, and Scotch of 1872-78, to Ireland?}

Such being a short account of how this question has been dealt with in England and Scotland since 1870, the subject I have to submit to you this evening is, is it feasible now, in 1879, to extend this beneficial system to Ireland?

The first matter that this brief history suggests for consideration is, that this legislation was commenced by eminent liberal statesmen in 1870 and 1872 , and has been cordially accepted and extended in 1876 and 1878 by the conservative statesmen who have succeeded them, thus the question is one not of party, but of social politics.

The next matter to observe is that Ireland is as to local government in exactly the same position as the districts of England and Wales that have not school boards. There are town councils, urban sanitary authorities, and boards of guardians on the English model; there are industrial schools and factory inspectors, and the system of factory inspectors is governed from London and not from Dublin.

Then the principle of paying school fees for poor parents out of 
local rates was recommended for Treland by the Royal Commissioners of Primary Education Inquiry in 1870, before it was adopted in England or Scotland.

The first conclusion which I would venture to submit to this Society is, that as compulsory education is a development of the protection of children, commenced by factory legislation, and extended by industrial school legislation, as factory legislation from its first commencement in 1833, and industrial school legislation since 1868, have been extended by parliament to Ireland, a prim $\hat{a}$ facie case exists for extending compulsory education to Ireland unless some reason can be shown to the contrary, or some difficulty in the way pointed out.

In support of this proposition I would venture to quote a few sentences from the remarkable speech with which Sir Robert Peel closed his career as prime minister in 1846 .

"He did not hesitate to say that in his opinion there ought to " be established between England and Ireland complete equality in " all civil, municipal, and political rights." " So that no person "viewing Ireland with perfectly disinterested eyes, should be " enabled to say a different law is enacted for Ireland, and on " account of some jealousy or suspicion Ireland has curtailed and " mutilated rights.

"That was what he meant by equality. Let no one think he " was making a reserve; he spoke of the spirit in which they ought " to legislate.

" He thought it ought to be impossible to say that there is a " different rule, substantially, with regard to the civil or municipal "franchise in Ireland from that which prevails in England."

Some twenty years before that speech, Sir Robert Peel had assimilated the Irish and English criminal law in 1828, and his work is completed at the end of half a century by the proposed common criminal code for England and Ireland of 1879.

Now if it be thought wise to have a common criminal code, is it not inconsistent with that principle to have it an offence for a parent to neglect the education of his child in England and no offence for a parent to neglect the education of his child in Ireland?

\section{III.-Are there any Statistics to show whether Compulsory Education is as much required in Ireland now, as it was in England in 1870, or in Scotland in 1872?}

In opposition to the proposal of complete assimilation in the matter of compulsory education, it may be said that so far back as the administration of Earl Grey, when the late Earl Derby (then Mr. E. J. Stanley) was Chief Secretary for Ireland, the State took 
charge of Irish education some years before it undertook the care of education in England, and that it did so on certain principles which have been developed into a great system, and so there might possibly not have been the same necessity for compulsory education in Ireland as in England or Scotland.

We have on this matter a very simple and conclusive test to appeal to, namely, the educational statistics collected in the three parts of the United Kingdon at the census of 1871, which coincides very closely with the dates of the English legislation of 1870, and Scotch of 1872.

The age periods in the English and Scotch statistics, 5 to 15, agree, the Irish statistics differ, owing to that want of uniformity in statistics so much to be deplored, and are from 5 to 16 years of age.

I have, however, made the corrections in the Irish figures by deducting all the children in the population between 15 and 16 , without deducting any from the children in attendance for those between the ages of 15 and 16 .

The results are shown in the following tables, 1, 2, 3.

School Attendance, 1871.

\begin{tabular}{|c|c|c|}
\hline & Number. & Per Cent. \\
\hline 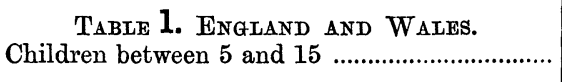 & $5,130,765$ & 100 \\
\hline 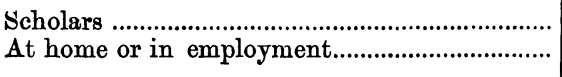 & $\begin{array}{l}3,123,785 \\
2,006,980\end{array}$ & $\begin{array}{l}61 \\
39\end{array}$ \\
\hline $\begin{array}{c}\text { TABLE 2. ScotLAND. } \\
\text { Children between } 5 \text { and } 15 \ldots \ldots \ldots \ldots \ldots \ldots \ldots \ldots \ldots \ldots \ldots \ldots \ldots\end{array}$ & 776,871 & 100 \\
\hline $\begin{array}{l}\text { Scholars } \\
\text { At home or in employment }\end{array}$ & $\begin{array}{l}54,1,895 \\
234,976\end{array}$ & $\begin{array}{l}70 \\
30\end{array}$ \\
\hline 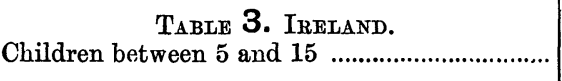 & $1,261,960$ & 100 \\
\hline 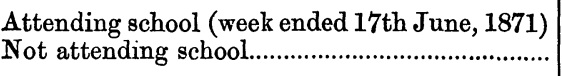 & $\begin{array}{l}576,312 \\
685,648\end{array}$ & $\begin{array}{l}46 \\
54\end{array}$ \\
\hline
\end{tabular}

It appears from these tables that compulsory education was thought necessary in England when only 39 per cent. of the children between 5 and 15 were in non-attendance at school. In Scotland similar legislation was thought necessary though only 30 per cent. were in non-attendance.

The proportion not attending school in Ireland in 1871 was 54 per cent.

It may be said, however, that this is only based on figures so far 
back as 1871, and there has been an increase in the daily average number attending school since 1871. This does not, however, bring the Irish proportion near the English or Scotch.

The Irish national schools show an increase of daily average number from 1870 to 1877 of only i6 per cent. In England and Wales the State aided schools show in the same time an increase in the daily average of 80 per cent. In Scotland the increase from 1872 was 70 per cent.

There are, besides, other recent figures by which to test the matter; of 597 children committed to industrial schools in Ireland in 1877 (the latest published figures), of 8 years of age and upwards, no less than 309, or 52 per cent., were totally ignorant. If we take all the children under 8 , as well as above, the proportion reaches 60 per cent.

Then taking the comparative education of prisoners in Ireland and in England and Wales, the figures are as follows:-Of men and boys 29 per cent. in England and Wales in 1875-76 could not read or write; in Ireland the proportion in 1877 was $3^{8}$ per cent.; of women and girls, the English proportion of ignorant was $3^{8}$ per cent., and the Irish was 54 per cent.

Thus whether we take the figures of 1871 or the figures of 1877, the inferiority of Ireland to England and Wales in the matter of education is placed beyond a doubt.

\section{IV.-What are the Modifications of English Acts of 1870-76 Necessary in Extending them in Ireland?}

As the compulsory clauses of the English Act are entirely independent of school boards, and apply to all the districts of England and Wales that are not under school boards, it is obvious that it is wholly unnecessary to postpone extending the benefits of compulsory education to Ireland until school boards are established; the whole question is thus reduced to the much simpler one of constituting school attendance committees.

Committees are in England to be appointed by guardians of the poor in all places except towns under town councils, or where urban sanitary authorities are by special order allowed to appoint them, where they are to be appointed by the town council or urban sanitary authority.

In extending this system to Ireland, there is a statutable disability to be borne in mind. In Scotland the parochial minister is an ex officio member of the local poor law board. In England clergymen are not excluded from being guardians, whilst they are excluded by statute from being guardians in Ireland. As clergymen are not excluded from school boards in England or Scotland (the majority, 8 out of 15, of the present Edinburgh school board 
being clergymen), it would be wise to provide that the highest dignitary or senior minister of each of the two religious denominations that are most numerous in the union or town should by himself or named deputy, be an ex officio member of the school attendance committee. Again, it would be desirable in the constitution of those committees to introduce the principle of cumulative voting, so as to secure the representation of minorities, and not to limit the selection to members of the bodies appointing only.

In my evidence before the select committee on the local government of towns in Ireland in 1876, I recommended the introduction of cumulative voting, and I desire again to record my opinion that in the divided state of feeling in Ireland, there is no part of the United Kingdom where it is of more importance to introduce the system.

It is a misfortune that it was not introduced in the Reform Act of 1868, and the earliest opportunity of the creation or reconstruction of any new local authority in Ireland should be used to introduce a principle which has been so successful in England and Scotland in softening differences and in inducing people of different views to work together for the public good.

To school attendance committees constructed on any fair principle to secure the representation of all who are interested in the matter, there would be no difficulty in entrusting the powers conferred on such committees by the English Elementary Education Act.

\section{V.-Existing Facilities for the Adoption of the System of Compulsory Education in Ireland.}

Having explained how easily the system of English school attendance committees could be extended to Ireland, I have next to call your attention to some facilities for carrying out the system in which Ireland is much in advance of both England and Scotland.

The efforts of the State in Ireland since the commencement of the century-first in assisting voluntary societies, then in the expenditure of the Lord Lieutenant's School Building Fund, and since 1830 in the large annual grants to the National Board, with the rival efforts of persons and societies to promote denominational schools-have led to Ireland being studded with school-houses.

Then the large grant of $673,000 l$. a-year from the general taxes, under the excellent management of the National Board, has secured a large and efficient staff of schoolmasters. The questions which have been raised as to them is not any defect of numbers, but as to shortness of pay and want of superannuation. Again, the schools are so generally accepted by the people, that the children appear on the school rolls in great numbers; the defect is therefore not 
in schools or in schoolmasters, but in attendance. This is shown in a very marked manner in a table published by the Irish Census Commissioners in 1871.

TABLE 4.-Attendance at School in Ireland, Year ended 31st March, 1871.

\begin{tabular}{|c|c|}
\hline \multirow{2}{*}{ Under 5 days } & Number. \\
\hline & $35,73^{6}$ \\
\hline Five days and under 20 days............................. & I I 2,444 \\
\hline Twenty days and under 40 days & $129,45^{\circ}$ \\
\hline Forty days and under 80 days ........................ & $2,18,982$ \\
\hline Total under 80 days & 496,612 \\
\hline Eighty days and upwards ............. & $49^{8,198}$ \\
\hline 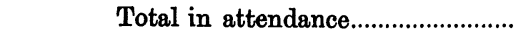 & 994,810 \\
\hline
\end{tabular}

From this table it appears that of $1,000,000$ children attending at some time of the year, only 50 per cent. attended 80 days and upwards; 22 per cent. attended between 40 and 80 days; i 3 per cent. between 20 and 40 days; i I per cent. between 5 days and 20 days; and 4 per cent. less than 5 days. This shows that the schools are conveniently situate, and that the parents who place so many children on the rolls have no objection to their children attending the schools. Let us consider for a moment what a change in the figures would be effected by the moderate compulsion of requiring the children to attend 80 days out of the 276 the school is usually open. By this change the adequate attendance would be raised from 36 to 72 per cent., as shown in the following tables :-

TABLE 5.-Attendance at School in Ireland, Year ended 31st March, 1871.

\begin{tabular}{|c|c|c|}
\hline & Number. & Per Cent. \\
\hline Children between 5 and 16 & $1,368,826$ & 100 \\
\hline $\begin{array}{l}\text { At school } 80 \text { days and upwards } \\
\text { from } 1 \text { to } 79 \text { days } \\
\text { Not at school at all }\end{array}$ & $\begin{array}{l}498,198 \\
496,612 \\
374,016\end{array}$ & $\begin{array}{l}36 \\
36 \\
28\end{array}$ \\
\hline
\end{tabular}

TABLE 6.-Effect of Compulsion on Children on School Rolls in Irelaind in 1871.

\begin{tabular}{|c|c|c|}
\hline & Number. & Per Cent. \\
\hline Children between 5 and 16 & $1,368,826$ & 100 \\
\hline $\begin{array}{l}\text { At school for } 80 \text { days and upwards } \\
\text { Not at school at all }\end{array}$ & $\begin{array}{l}995,810 \\
374,016\end{array}$ & $\begin{array}{l}72 \\
28\end{array}$ \\
\hline
\end{tabular}

This amount of compulsion would require little trouble or 
expense to effect. The names of children on the school rolls would afford a ready means of ascertaining all those whose attendance is below 80 days.

There would no doubt be payment of school fees out of rates, but if this did not attain greater dimensions than in Scotland, at the end of five years it would not amount to more than 10,000 l. a-year, and in 1875 Parliament, in passing the National School Teachers' Act, 38 and 39 Vict., cap. 96, decided that it would be desirable to increase the remuneration of Irish schoolmasters from local rates. The schoolmasters would further gain by the school fees from the parents able to pay, and if these were arranged on a scale or at higher rate for shorter attendance, this would produce a legitimate increase to the schoolmaster's income.

In Scotland the working of the Act was at first somewhat marred by the prosecutions being all entrusted to local crown solicitors, which involved considerable expense. This has been remedied by the Act of 1878. In Ireland whilst the initiation of prosecutions would rest with the school attendance committees, as in England and Scotland, they might all, like other violations of statutes, be entrusted to the constabulary to conduct, so that there would be no costs except for petty sessions stamps; this would bring the system to the same as in England, where the penalty, including costs, is not to exceed $5 s$.

The proceedings would thus be facile, cheap, and not oppressive; and when 20,000 parents were prosecuted in England and Wales in 1877 , this would give as corresponding figures 4,500. But as other offences against parental duty are about two-thirds the English proportionate figure, the prosecutions of parents in Ireland may be estimated not to exceed 3,000.

The example of these cases would check others, and so whole classes of offences commencing with neglect of parental duty would be nipped in the bud.

Another element of expense in Scotland and England would be much less in Ireland: as the Royal Irish Constabulary collect each year the agricultural statistics in great detail, they could for a very trifling expense collect the additional information as to children between 5 and 13 that were not on school rolls, distinguishing those that did or did not reside within 2 miles of a school. In this way the school attendance committee would be promptly and at small cost, supplied with full information for dealing with neglect not disclosed by school rolls; they would too have placed before them at a glance the parts of their district where there were children beyond the 2 miles' limit recognised in England, and so would know the exact requirement, if any, for new or additional schools. 


\section{VI.-General Results to be Expected from the Constitution of School Attendance Conmittees with a View to Compulsory Education.}

One advantage that would arise from the constitution of these local school attendance committees, would be that the Irish education question would be presented to those bodies in its true aspect of investigation, how the duty of each parent was discharged towards his children in the matter of education, and of seeing that every child had justice done to it, and was being properly educated. It would be no longer a point of favouring one system or condemning another, but of testing how each parent acted under the system he himself approved of. In this way there is every reason to expect that the long contest between mixed and denominational education would be brought to a close, and that all earnest endeavours to promote education in accordance with the feelings and wishes of parents would be necessarily accepted, and receive equal treatment from the State.

Some thirteen years ago, when invited to address the Industrial and Reformatory School Union at the Manchester meeting of the Social Science Congress, I ventured to point out that industrial schools were as much required in Ireland as in England or Scotland, and that it was discreditable to our legislation to omit Ireland from the consolidated statute of 1866 , which amended the code introduced in England and Scotland in 1861.

When some Irish members in the next session introduced a Bill to establish industrial schools on the English and Scotch plan in Ireland, they were met by the argument that the State was pledged to mixed education in Ireland, and that industrial schools were necessarily denominational. It was found, however, that that view could not be sustained in debate, and industrial schools were conceded to Ireland by large majorities in the Commons, and by a total absence of opposition in the House of Lords, and at the beginning of 1878 there were 4,854 children protected by these institutions, as compared with 1,852 in an equal portion of the population of England and Wales.

There can be no doubt that compulsory education, which is really an extension of the principle involved in industrial schools, tends to a similar conclusion, as the enforcement of parental duty under our free constitution necessarily involves the utmost parental liberty in the selection of the school. It changes the action of the State from the ambitious rôle of enforcing a system, to the more modest but more useful task of making certain of securing a satisfactory result.

In considering why this measure of compulsion has been so cordially accepted and developed in Scotland and England, the

VOL. XLII. PART II.

2 H 
extent to which the State has studied the wishes of the people should be well considered.

The Scotch Act of 1872 contains the preamble- " Whereas it has " been the custom in the public schools of Scotland, to give instruc" tion in religion to children whose parents did not object to the " instruction so given, but with liberty to parents, without for" feiting any of the other advantages of the schools, to elect that " their children should not receive such instruction, and it is " expedient that the managers of public schools shall be at liberty " to continue said custom."

Under this rule, in nearly all the board schools in Scotland, the schoolmaster is required to be well fitted to give religious instruction, and does give it subject to the conscience clause.

Besides these schools, so religiously conducted in accordance with the usages and wishes of the people, which receive $355,000 l$. a-year of the general taxes, grants are made out of the general taxes of I 10,00ol. a-year to denominational schools, of which the Roman Catholic schools receive 19,000l. a-year. When school fees are paid out of local rates, the parent may select any school that receives the parliamentary grant, so that local taxes as well as parliamentary grants can be and are applied to denominational schools in Scotland.

In England and Wales only 452,000l. is granted out of the general taxes to board schools, and 202,000l. to British and other schools, while no less than $\mathrm{r}, 344,000 \mathrm{l}$. is given to denominational schools, of which Roman Catholics get 109,000l. a-year.

Again, in England as in Scotland local rates can be applied to pay school fees for poor parents at denominational schools, the school being selected by the parent; and Her Majesty's Inspectors of Schools are instructed "to maintain an entire impartiality " between Schools under different kinds of management, and to " avoid even the appearance of using their influence in favour of " either Voluntary or Board Schools, or of taking a part in local " differences in these matters;" and also, "that the Privy Council "decline to interfere respecting the choice of books."

These arrangements, accompanied by the stringent conscience clauses, make compulsory education acceptable in England and Scotland, because it is truly and bona fide confined to the enforcement of parental duty.

In Ireland the part of the entire vote of $673,029 l$., comparable to the above English and Scotch figures $(568,000 l$.), is given to board schools alone. And in striking contrast to the English system, no school can share in the grant unless the books are approved of by the State appointed board, and unless the inscription National School is put up in the school without the addition of any title of 
denominational character. The Christian Brothers, who after trying the State system in Ireland for a short time, withdrew in 1836 on conscientious grounds, not only receive no State assistance, but have had some of their endowments confiscated under the exception in the Roman Catholic Emancipation Act of 1829, which, strangely enough, still exists (ten years after religious equality has been so amply conceded to Ireland), and under which they are liable to be indicted for being in Ireland at all.

This confiscation by judicial decision has taken place since the report of the Royal Commission on Primary Education of 1870, the majority of whose members recommended that the rule of the national board as to religious instruction being confined to fixed hours, should apply solely to places where there was only one school for children of different denominations to resort to; but that where a Protestant and Roman Catholic school had both been in operation for upwards of three years in the same town or district, that a rule might be adopted which would allow Christian Brothers and other denominational schools to receive State assistance without departing from their principles.

The extreme diversity of State policy in Ireland as compared with England and Scotland, is shown at a glance in the following Table :-

TABLE 7.-School Votes from General Taxes.

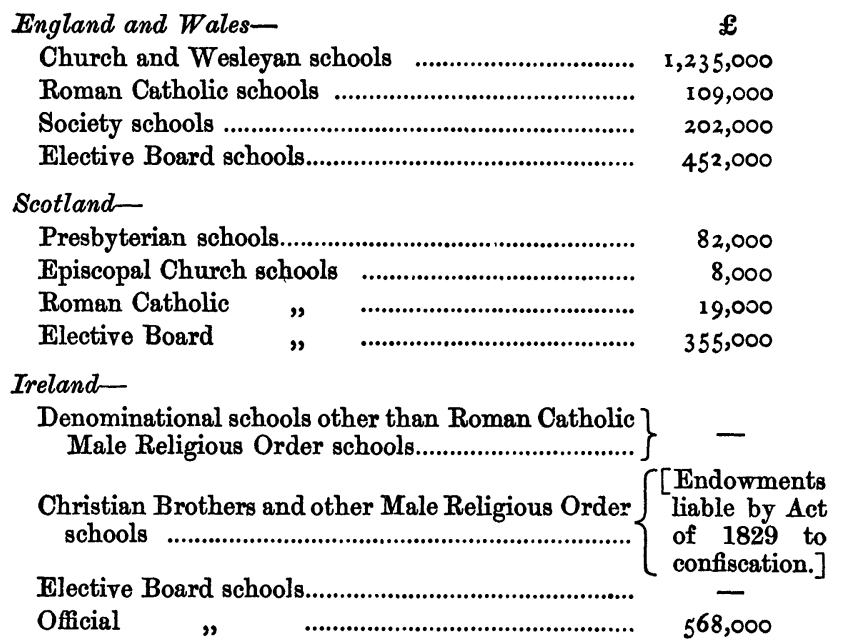

The diversity of State policy on education in Ireland and in England explains why no demand* has been made for compulsory

* The question was raised but not pressed by Mr. O'Shaughnessey, M.P., in a debate in the House of Commons, on his resolution respecting primary education 
education in Ireland. This diversity has, however, lasted so long that if compulsory education is to be accepted as a boon in Ireland, it would be wise to precede or accompany its enactment with some marked evidence that it is the enforcement of parental duty which is alone intended, and that it is not part of any policy of extending State interference or abridging the liberty of teaching in accordance with any foreign precedents.

The best steps to afford this evidence would be first the repeal of the exception in the Roman Catholic Emancipation Act of 1829, under which bequests to the Christian Brothers' Institution and other Religious orders have been declared void, and secondly, the adoption of the principle of the recommendations of the Primary Education Commissioners of 1870, under which denominational schools might share in the educational grant in all places where they were not the sole public school within the English 2 mile limit, and there were other schools to secure that their system was not forced on any who objected to it.

\section{VII.-Imperial Nature of the Question of Compulsory Education in Ireland.}

I cannot conclude without saying a word or two upon the imperial nature of the question which I have ventured to intrude upon your notice.

As primary education in Ireland has not been entrusted to local school boards as in England and Scotland, the responsibility of the results rests with the Imperial Parliament, and with all those thinkers, writers, and speakers who influence the public opinion of the United Kingdom, by which the decisions of parliament are so largely influenced.

This Irish education question affects the whole United Kingdom in another way which has not been at all sufficiently appreciated.

This arises from the extent of migration of the Irish people to Great Britain, which, commencing with the introduction of steamboats, was accelerated by the great famine of 1846-47.

The figures are as follows:-

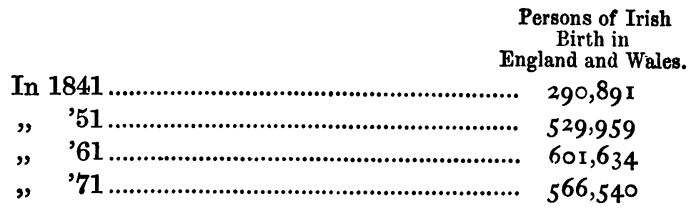

in Ireland, 16th March, 1877. Mr. Butt pointed out the want of State recognition of voluntary effort in denominational education as the impediment to compulsion in Ireland. The concession I have suggested on this point, and the facts and suggestions in the paper meet, I find, most if not all of the objections to compulsion urged in the debate. 
The number in Scotland in 1871 was 207,770 , making in Great Britain 774,310.

These figures are familiar to all those who have examined the statistics of the census, but the way in which persons of Irish birth are distributed as to age and as to the part of the country in which they reside, has not attracted the same attention. The figures are shown in the following tables:-

Table 8.-Proportion Above and Under Twenty Years of Age of Persons of Irish Birth and Non-Irish Birth.

(a) In England and Wates. Total

Under 20 years of age...

Twenty years and upwards

(b) In Scotrand.

Total

Under 20 years of age...

Twenty years and upwards

\begin{tabular}{|c|c|c|c}
\multicolumn{2}{|c|}{ Irish Birth. } & \multicolumn{2}{c}{ Non-Irish Birth. } \\
\hline Number. & Per Cent. & Per Cent. & Number. \\
\hline & & & \\
566,540 & I00 & I00 & $22,145,726$ \\
\hline 67,807 & 12 & 47 & $10,314,646$ \\
498,733 & 88 & 53 & $11,831,080$ \\
\hline & & & \\
207,770 & 100 & 100 & $3,152,248$ \\
\hline 29,974 & 14 & 49 & $1,538,132$ \\
177,796 & 86 & 51 & $1,614,116$ \\
\hline
\end{tabular}

TABLE 9.-Proportion of Adults of Irish Birth to Adults of Non-Irish Birth in Town and Rural Districts.

\begin{tabular}{|c|c|c|c|}
\hline & Irish Birth. & Non-Irish Birth. & Propurtion. \\
\hline $\begin{array}{l}\text { (a) IN ENGLAND AND WaLES. } \\
\text { Twenty years and upwards }\end{array}$ & $49^{8,733}$ & $11,831,080$ & 一 \\
\hline $\begin{array}{l}\text { In } 63 \text { chief towns } \\
\text {, rest of England and Wales ..... }\end{array}$ & $\begin{array}{l}282,375 \\
2,16,35^{8}\end{array}$ & $\begin{array}{l}4,025,4,28 \\
7,805,652\end{array}$ & $\begin{array}{l}\text { I to } 14 \\
\text { I }, 36\end{array}$ \\
\hline $\begin{array}{c}\text { (b) IN Scotrand. } \\
\text { Twenty years and upwards }\end{array}$ & I 77,796 & $1,614,116$ & - \\
\hline $\begin{array}{l}\text { In } 22 \text { chief burghs } \\
\text {, rest of Scotland }\end{array}$ & $\begin{array}{r}101,207 \\
76,5^{89}\end{array}$ & $\begin{array}{r}590,622 \\
1,123,494\end{array}$ & $\begin{array}{l}x \text { to } 6 \\
\text { I } \Rightarrow 4\end{array}$ \\
\hline
\end{tabular}

It will be seen from Table 8 that amongst persons of Irish birth nearly 88 per cent. in England and 86 per cent. in Scotland are of 20 years of age and upwards.

Then from Table 9 it appears that the great majority of those of 20 years of age and upwards reside in the chief towns.

For this purpose $I$ have taken the sixty-three chief towns shown in the English census and the twenty-two chief burghs shown in the Scotch census. 
In these towns, taken in the aggregate, persons of Irish birth of 20 years of age and upwards are as I to 14 of those of the same age of non-Irish birth. In some of the towns the proportion must be still larger than this.

In the rest of England and Wales the proportion is only as I to 36 .

In the twenty-two chief burghs in Scotland the proportion of persons of 20 years and upwards of Irish birth to those of same age of non-Irish birth is 1 to 6, whilst in some of the towns they form a much larger element of the adult population; in the rest of Scotland the proportion is as high as I to I4.

The extent of migration of persons of Irish birth thus disclosed has a very marked effect in bringing Irish labourers in direct competition with the labourers of England and Scotland. Any inequality in the encouragement by the State (out of imperial or local taxes) of the education of the labouring classes in Ireland as compared with those in England and Scotland involves an injury to the rising generation of Irish labourers in their competition for wages.

In their close contact with their English and Scotch fellow labourers which these statistics prove, they have forced upon their attention to an extent that the wealthier and more educated classes little think or know of, all the differences in the laws on this question of education and in the assistance to the poor, whether in payment of school fees or otherwise under the poor law, and when they find that the State takes greater care of children and of the poor in one part of the United Kingdom than in another, and pays greater respect to the feelings of some religious denominations than others, it is impossible to expect diversity of law and policy not to be an element in creating dissatisfaction.

In their migration in search of wages they have been brought in largest numbers into those parts of the United Kingdom where since 1868 the largest political power and privileges have been conceded to the class to which they belong. Any legitimate cause of dissatisfaction thus has a tendency to be a complication not alone in Irish but in imperial politics.

The remarkable migration which has a tendency to create this complication, at the same time, in the most irresistible manner, consolidates the union of the three kingdoms; but it no less irresistibly points as the solution of this and the remaining difficulties of the Irish question, to the policy to which at the commencement of this paper I ventured to call your attention, as enunciated some thirty years ago by Sir Robert Peel at the close of his career as Prime Minister.

"There ought to be established between England and Ireland a " complete equality in all civil, municipal, and political rights, so 
" that no person viewing Ireland with perfectly disinterested eyes " should be enabled to say a different law is enacted for Ireland, " and on account of some jealousy or suspicion Ireland has curtailed " and mutilated rights."

\section{VIII.-Summary of Conclusions.}

I will now briefly repeat in a condensed form some of the leading conclusions of the preceding paper.

1. That compulsory education is more wanted in Ireland than it was when introduced in England in 1870, or in Scotland in 1872.

Children between 5 and 15 not attending school at one time being 54 per cent. as compared with 39 per cent. in England, and 30 per cent. in Scotland.

2. That the compulsory clauses of Mr. Forster's English Elementary Education Act of 1870, as amended by Lord Sandon's Act of 1876 , might with appropriate modifications be advantageously extended to Ireland.

3. That Ireland being in the same position as the districts of England and Wales not under schnol boards, might have school attendance committees constituted like the English committees under the Act of 1876 for such districts, and so might have the benefits of compulsory education conferred without waiting for school boards.

4. That in constituting school attendance committees (to obviate the effect of the statutable exclusion of clergymen from boards of guardians in Ireland which does not exist in England or Scotland), the bighest dignitary or senior minister of each of the two religious denominations that had the greatest number of inhabitants in the union or town, should in person or by deputy, be an ex-officio member of the school attendance committee.

5. That the other members of the school attendance committee should be selected by cumulative voting of the board of guardians in rural districts, and of the town councils or Urban Sanitary Authorities in towns.

6. That the statistics of children not on school rolls, and residing more than 2 miles from a school, might be collected by the Royal Irish Constabulary, along with the agricultural statistics, each year, so as to show from time to time the exact want of primary schools.

7. That prosecutions should be conducted by the police, but only after certificate from school attendance committee of gross and inexcusable neylect of parental duty.

8. That as evidence that compulsion was extended to Ireland solely for the purpose of enforcing the performance of parental duty, and not for the purpose of restricting the freedom of educa- 
tion, the extension of compulsion should be preceded or accompanied with a repeal of the exceptions in the Emancipation Act of 1829, under which Christian Brothers and other Religious Orders have had their endowments confiscated, and with the adoption of the recommendation of the Commissioners of Primary Education in Ireland, which would allow of denominational schools sharing in the parliamentary grant in all districts where there were other schools to provide for those who objected to the system.

9. That the adoption of school attendance committees on a fair basis in Ireland by concentrating attention on the manner in which the duty of each parent was discharged towards his children, would have a tendency to terminate the long contest between mixed and denominational education, as all earnest endeavours to promote education in accordance with the feelings and wishes of the parents would be necessarily accepted and receive equal treatment from the State.

\section{Discussion on Dr. W. NeILson Hancock's Paper.}

The Right Hon. James Stansfeld, M.P., said that he would have preferred to hear some discussion before venturing to offer any remarks of his own, but he was extremely glad to have the opportunity of meeting Dr. Hancock in London, and with many other inquiring Englishmen, he had reason to be grateful to him for a most hospitable reception in the capital of the sister isle. Those who had visited Ireland and known him there would be aware how influential he was in that country and in the capital, and that he took an unceasing interest in every question which concerned the welfare of Ireland. It appeared to him that Dr. Hancock in his paper had made good a considerable part of the propositions which he desired to establish, though in some respects further explanation might be desirable. He supposed they ought to be agreed, after the statistics they had heard, that as far as the condition of education in Ireland was concerned-the want of education and the need of procuring a greater attendance of children-there was at least as great necessity, if not greater necessity, for compulsion or some equivalent means of securing attendance in Ireland, as existed in England or Scotland in 1870 or 1872 . Then came the practical question how that principle was to be applied, and whether it could be applied in Ireland as it had been applied in England and Scotland. Although the matter was being discussed before a scientific society, it was a sort of political question, but the political views must be regarded and discussed from a philosophical point of view. They would not be justified in endeavouring to solve this question purely from an English point of view, the condition of things and 
the facts in Ireland being different from the condition of things and the facts in England and Scotland. In England, although there were the Established Church, and a number of dissenting bodies, there was not so marked a division as between the Protestant and Roman Catholic population of Ireland. In England compulsion had been brought to bear without much injustice to the conscience of parents, or the rights of parents or children. He would like to know whether Dr. Hancock considered that a statesman might not find greater difficulty in applying the principle of compulsion as he proposed in Ireland. In some parts of Ireland the population was almost exclusively Roman Catholic, the Protestant population being so sparse that Protestant children for the most part would live beyond the reach of schools, or the schools would be at an unreasonable distance. Compulsion should not be brought to bear upon children till measures had been taken to provide schools at which they could be reasonably expected to attend. The principle of compulsion should not be applied to the whole population merely for the purpose of securing the attendance of the majority of the children, the minority being left out. This difficulty was one of money more than anything else, and he therefore regarded it as not insuperable. Everyone present would be of opinion that money spent for the object of securing the education of the poor child-population of the country, and succeeding in that object, could not be spent in a better way. There were often discussions in the House of Commons upon the subject of economy, but he might say for himself and for their chairman, that neither of them had ever taken the narrow and unphilosophical view that economy consisted in the non-expenditure of money. He believed that saving was economy, but that profitable expenditure was still greater economy. He thought it would be the general opinion that Dr. Hancock had proved his case, so far as to show that there was need for compulsion to be applied to the education of the children of Ireland, and that there would be a justification for the application of the principle when it could be shown that every child in Ireland, and every parent in the performance of duty towards the child, had the opportunity of securing that education. That education would not be obtained by compulsion only, but it must also be secured as a fact that an efficient school at which a child could be compelled to attend should be brought within the reach of the child and of the parents.

Professor Jevons, F.R.S., said that his acquaintance with Irish affairs did not qualify him to discuss a paper which dealt with Irish legislative difficulties, but he might nevertheless say that Dr. Hancock's arguments and figures seemed to be altogether conclusive as to the necessity for the extension of the English educational law to Ireland. There might be pitfalls and difficulties unknown to him, but in a statistical point of view the paper apparently placed the question beyond further doubt. They were a scientific society, and he did not think it was their duty before they expressed an opinion to take into account every difficulty that legislators might meet with. When the question 
came before parliament, which he hoped it would do before long, it would be for the Government to see whether the religious difficulty was insuperable. Not many years ago the religious difficulty in England was thought to be insuperable, but within the last seven or eight years, it had almost vanished. With respect to the latter part of Dr. Hancock's argument, no doubt it was based on a selfish view of the matter. Irish education should be regarded primarily as a benefit to the Irish people, not to ourselves. But even if regarded from an English point of view, it was a very important matter. English workmen and trades unions might object to have poor ignorant Irish labourers brought over to contend with and under-bid them. Dr. Hancock had shown that there is, especially in the towns, a serious number of poor Irish labourers, and he quite agreed that the congregating together of poor ignorant Irishmen might be the source of very grave evils. It could not be known how much mortality, drunkenness and crime might be ultimately due to the ignorance of those allowed to grow up uneducated in Ireland and who migrated here. He hoped that some good practical result might ensue from the statistics which Dr. Hancock had submitted.

Mr. S. Bodrne said that the question of education generally was one of very great interest to him. True education was the greatest blessing which could be conferred upon any human creature. He demurred to treating this matter altogether from a statistical point of view. He thought it a danger attending such discussions as this Society pursued, that there was too much inclination to resort simply to the details of mere figures, and to put out of sight the far higher consideration of what those figures tended to, and what were the objects to be pursued in seeking for the welfare of the country generally. He agreed with Professor Jevons that the religious difficulty existing in England had become almost extinct; but he felt that it had been by agreement in the wrong direction. He feared that the difficulty had been got rid of by acting as if mere education in reading, writing, science, and art were of the highest importance, and neglecting moral and religious training. This was not a state of things calculated to increase the happiness of the people of our land, or enhance the greatness or glory of our country. He felt that they must make the results which mere figures could show subordinate to the higher consideration that the moral and religious welfare of the people is of the highest importance. The more they departed from the higher objects which could be attained in training up young people, the greater danger there was of the spread of the spirit of latitudinarianism, and the greater would be the difficulties in the way of promoting the welfare of the country. He did not speak in the sense of any denominational view, because he believed that what was wanted was not to raise up members in any religious sect or party, but to teach the higher duties which are owed by us all to our Maker, and to increase that spirit of charity, love and harmony which ought to pervade all classes of society, and on which he believed the good government of the land and the happiness and welfare of 
the people entirely depended. He felt that they were in danger of losing sight of those great objects, and that therefore they must not depend too much upon what was shown by figures, but discuss more fully the principles by which they were guided, and not keep out of sight that which, to his mind, was of essential importance.

Mr. Thomas BRETT agreed very much with the general tenor of Dr. Hancock's paper, but his arguments in favour of his proposition that in constituting school attendance committees, to obviate the effect of the statutable exclusion of clergymen, the highest dignitaries should be placed upon the boards, failed to carry conviction to his mind. Dr. Hancock said that Ireland at the present time was in the condition of that portion of England which has no school boards. Dr. Hancock had shown that Ireland was far behind England and Scotland in education, and therefore any analogy drawn from the portion of England not under school boards, presumably the more advanced portion of the country, and applied to the education of Ireland, would lead to a great many fallacies and delusions. Statutable disability of the clergy was deplorable, and he considered it should be removed. He objected to a clergyman being ex officio a member of the school attendance committee; but he would be the last to deny a clergyman that position if he gained it by election. The difficulty he had observed was that wherever Church of England clergymen, priests, Presbyterian, Wesleyan, and other ministers met, there was a spirit of religious intolerance. They were often exceedingly well-disposed men, but as a rule their desire was first to advocate their own religion or creed, and secondly to advance the interests of education. He did not think that Dr. Hancock's proposition in favour of the clergy would work well, either in England, Scotland, or à fortiori in Ireland.

The PRESIDENT believed that there was so much unanimity upon Dr. Hancock's paper, that there was hardly material for discussion in the ordinary sense of the term. He would therefore content himself with moving a vote of thanks to Dr. Hancock. He need hardly remind them that Dr. Hancock was a most distinguished member, and he believed the founder of the Irish Statistical Society, whose contributions to political economy had been most valuable. He had himself largely consulted Dr. Hancock's works, and had found them a perfect mine of wealth upon matters not only relating to Ireland, but to England also. He could fully confirm what had been said by Mr. Stansfeld, as to the assistance which Dr. Hancock was always ready to give to those who were interested in Irish questions. He had himself availed himself of that assistance in a Irish subject, on, which he had been engaged the last two years, and he was glad to have that opportunity of stating the immense obligations he was under to Dr. Hancock, without whose assistance it would have been impossible for him to have succeeded.

With regard to the paper before them, the facts brought forward by Dr. Hancock threw much light upon the subject of education 
in Ireland. He had been under the belief that the great bulk of the Irish children were educated, and would bear favourable comparison with the children in this country at the present time, and much more favourable comparison a few years ago. The result of the figures brought forward by Dr. Hancock, showed that education in Ireland is far behind education in England and Scotland. It therefore seemed to him that it would be of the highest possible advantage to extend to Ireland the compulsion which England and Scotland now enjoyed. He was surprised that no Irish member had recently brought before Parliament the state of things in Ireland. He had listened with great interest to the part of the paper which showed the proportion of Irishmen in England, and also the very large proportion of those Irishmen who were fully grown men. The neglect to take this into account would probably account for many of the fallacies which writers had fallen into in comparing the crimes of Irishmen and Englishmen. It was quite possible that if they took into account the difference of age of Irishmen living here, they might account for differences in the proportion of crime and drunkenness, which some persons attributed rather to race than to other causes. However important it might be to Ireland that compulsion should be extended there, and that the education of the people should be improved, it was just as important to England, considering the large proportion of Irishmen who come here and mix with the population, and therefore have a bearing upon the people of this country. Looking upon the question from an English or Irish point of view, it appeared to be equally desirable that the system which in England and Scotland had been carried out with so much success, should be extended to Ireland. He did not believe it was beyond the scope of practical statesmanship to cope with the religious difficulty, and to extend to Ireland the benefits of compulsory education. With these remarks he proposed a vote of thanks to Dr. Hancock, which he was sure that every member then present would most cordially give.

Mr. G. ERrington, M.P., in seconding the vote of thanks to Dr. Hancock, said he had not intended to address the meeting, but did so in order that it might not be supposed that the only Irish member present did not take an interest in this very important question. He congratulated Dr. Hancock upon his paper, which, while dealing with details, had still been exceedingly interesting. The question they were formally discussing was as to the possibility of introducing compulsory education into Ireland, but he thought they would feel they were in reality discussing the broader question as to how they could best advance the interests of education in Ireland. He thought, in spite of Dr. Hancock's arguments, that the question of introducing compulsory education into Ireland was, at the present time at all events, surrounded by enormous difficulties. Dr. Hancock had for instance suggested that the school attendance committees should be very much under the control of the clergy. His own impression was that unless they were under the conirol of the clergy they could not possibly be worked, but in case they were 
so placed there would arise other difficulties from the opposite interests involved, and elements of jealousy, and he was not sure that parliament at the present moment would be inclined to introduce any such arrangements, or eren face the question just now. He quite agreed, however, with Dr. Hancock as to the great need of beginning to lay the foundation of some system which should tend to alter the unsatisfactory condition of education which had been so picturesquely illustrated by the lecturer. He thought that might be done very completely by introducing some of the suggestions contained in Dr. Hancock's summary of conclusions. The public mind ought to be prepared for further necessary changes, by the portions of the Emancipation Act to which Dr. Hancock had referred being repealed. If that were done the ground would be to a great extent cleared, and it would be seen that in introducing this policy we did not desire in any way to compel consciences, but merely to press the enforcement of parental duties. All must feel the importance of insisting that all children should receive education of some sort; but he was bound to say that for the present he could not give his concurrence to all the views contained in the paper as to the feasibility or expediency of introducing compulsory education into Ireland at present.

Mr. Willans, in supporting the motion made by the Chairman, said that he had been particularly anxious to hear the views of gentlemen from the sister isle on a question which seemed to be so essentially one of Home Rule. But Dr. Hancock had taken the question out of the Home Rule sphere, and given reasons for treating it as an imperial one. They were much indebted to Dr. Hancock for his masterly paper, which was only in character with other papers for which they had been indebted to him during a series of years. He had shown them the necessity for conpulsory education in Ireland; and that if there had ever been a case for it in England and Scotland, there was a still stronger case in Ireland. In view of the large proportion of adult Irishmen who came over and settled here, entering into competition with our workmen, and in the course of a short time becoming electors in England and Scotland, it was of imperial moment that this large element of our population should not come over in a dense state of ignorance, but that they should be so educated as to be able to do their work, and discharge all their duties with intelligence. The religious difficulties would be far greater in Ireland than they had been with us. He was going to ask Dr. Hancock if, in those districts where denominational schools happened to be the schools which the children would be compelled to attend, the parents could rely upon their children obtaining education without sectarian instruction. That was the real difficulty that would have to be met in Ireland. He hoped, with the Chairman, that the statesmanship of the House of Commons would be able to get over it. Objection had been taken to the proposals in the paper for the appointment of clergymen on the school committees. He for one would prefer that no clergrmen of any denomination whatever should be a member of any sehool board or school committee, though he was able to cite 
instances in which clergymen had gone upon English school boards with the strongest prejudices against the Education Act of 1870, and the utmost jealousy of its interference with the national schools; bat the edges were soon rubbed off them, and they were now working admirably with their colleagues.

If they must have ministers of religion upon their school boards in Ireland, they ought to go simply upon election by the ratepayers; that would be the only tolerable settlement of that difficulty.

Dr. HANCOCK, in reply, said that he had been extremely gratified by the kind observations which had been made as to his paper; when he was asked to read a paper before the Society, he thought the best thing he could do was to give them an Irish question of sufficient difficulty to be worthy of their attention. What he wanted to present was the difficulty the English and Scotch people were responsible for, and Mr. Errington had appreciated the point as to getting rid of the offensive clauses in the Emancipation Act. The great difficulty was that Englishmen believed they had established religious equality in Ireland, but they had not done so. A committee of the House of Commons in 1872-on conventual and monastic institutions-inquired into that question, and he was greatly struck by the course of that inquiry. There were some influential members of the House upon the Committee. and an Irish member proved all the facts about the clauses of the Emancipation Act, and recommended that those clauses should be repealed. The committee adopted and reported to the House in full the statement of the grievances, but said the recommendation of the removal of the grievance was not referred to them, and the clauses remain unrepealed. In 1879, seven years afterwards, Irish members are blamed for not bringing forward the question of this violation of religious equality, but he considered that after the report of the committee in 1872, it ought to be brought forward by English or Scotch members. He could not defend Imperial Government in Ireland against those who were dissatisfied unless such disabilities were swept away. He found that the last instructions given by the Privy Council in England and circulated as a parliamentary paper to every Irish member, called special notice to the fact that the council did not interfere with the books in schools in England; but as to Ireland, the national board said that no grant should be given unless the books were approved of. Eighty per cent. of the children attended mixed schools. Legally they were mixed schools, i.e., open to all, but as a matter of fact it onght to be known that they were not mixed schools. The Presbyterians had their national schools, the Episcopal Church had their national schools, and the Roman Catholics had their national schools. What was the use of insisting on the rule that not one halfpenny of public money should be given if the word Presbyterian was put over Preslyterian schools, Roman Catholic over Roman Catholic schools, and Irish Church over Irish Church schools? It simply produced dissatisfaction and led to no practical result. As to the machinery by which attendance committees should be constituted, it should 
be borne in mind that he was not proposing school boards. $\mathrm{He}$ considered attendance committees as most probably only bodies of transition, and he wished to make a convenient arrangement for nominating people on them without expense. It was not fair to the clergy that they should have to be chosen by bodies in which they had not been allowed to sit, and he therefore proposed for the attendance committees to give them that position without election. He would take all the concessions that have been made in England or Scotland, and if it were desired that Ireland should be a contented part of the United Kingdom, it would be best for parliament to extend those privileges to Ireland in the completest possible manner, but at the same time with every possible consideration for Irish feelings and Irish ideas.

The Chairman having announced the subject of the next paper, the proceedings terminated. 